\title{
Bacterial-Plant-Interactions:
} \section{Approaches to Unravel the Biological Function of Bacterial Volatiles in the Rhizosphere}

\author{
Marco Kai ${ }^{*}$, Uta Effmert and Birgit Piechulla \\ Department of Biochemistry, Institute of Biological Science, University of Rostock, Rostock, Germany
}

Rhizobacteria produce an enormous amount of volatile compounds, however, the function of these metabolites is scarcely understood. Investigations evaluating influences on plants performed in various laboratories using individually developed experimental setups revealed different and often contradictory results, e.g., ranging from a significant plant growth promotion to a dramatic suppression of plant development. In addition to these discrepancies, these test systems neglected properties and complexity of the rhizosphere. Therefore, to pursue further investigations of the role of bacterial volatiles in

OPEN ACCESS

Edited by:

Paolina Garbeva,

Netherlands Institute of Ecology

(NIOO-KNAW), Netherlands

Reviewed by:

Kristin Schulz-Bohm,

Netherlands Institute of Ecology,

Netherlands

Alexander Weinhold

iDiv-German Center for Integrative

Biodiversity Research, Germany

*Correspondence:

Marco Kai

marco.kai@uni-rostock.de

Specialty section

This article was submitted to

Plant Biotic Interactions,

a section of the journal

Frontiers in Microbiology

Received: 09 September 2015

Accepted: 21 January 2016

Published: 09 February 2016

Citation:

Kai M, Effmert $U$ and Piechulla B

(2016) Bacterial-Plant-Interactions:

Approaches to Unravel the Biological

Function of Bacterial Volatiles in the

Rhizosphere. Front. Microbiol. 7:108.

doi: 10.3389/fmicb.2016.00108 this underground habitat, the applied methods have to simulate its natural characteristics as much as possible. In this review, we will describe and discuss pros and cons of currently used bioassays, give insights into rhizosphere characteristics, and suggest improvements for test systems that would consider in natura conditions and would allow gaining further knowledge of the potential function and significance of rhizobacterial volatiles in plant life.

Keywords: bacterial volatiles, mVOC, plant growth promotion, plant growth inhibition, rhizobacteria

\section{INTRODUCTION}

Volatile metabolites are important infochemicals mediating indispensable communication processes in all kingdoms of life (Hare, 2011; Dweck et al., 2015). The chemical nature of these small, lipophilic molecules enables plants attracting their pollinators or repelling pathogens, and animals finding mating partners (Hare, 2011; Mithöfer and Boland, 2012; Knollhoff and Heckel, 2014; Dweck et al., 2015). Current research indicates that volatiles released by bacteria play also a major role in multifarious microbial interactions, since these microbes release a wide range of various different volatiles, of which quite a few are capable to manipulate physiological processes in other bacteria, as well as in fungi and plants (Kai et al., 2009; Wenke et al., 2010, 2012; Effmert et al., 2012; Bitas et al., 2013; Audrain et al., 2015; Schmidt et al., 2015a).

Bacteria are omnipresent. They successfully occupy ecological niches as well as colonization hotspots like the plant rhizosphere. Plants release up to $40 \%$ of their photosynthetic fixed carbon through the roots into the surrounding area (Barber and Martin, 1976; Lynch and Whipps, 1991; Marschner, 1995; Hütsch et al., 2002). Due to this so called rhizodeposition, they attract a tremendous diversity of microorganisms (Perry et al., 2007). Bacteria preferably colonize the root itself (rhizoplane) and the adjunct soil zone (rhizosphere; Lenc et al., 2011; Bulgarelli et al., 2013; Reinhold-Hurek et al., 2015) representing thereby a crucial link between the plant roots and the surrounding soil. They take advantage of a constant flow of organic plant-based substrates, but 
in return promote plant growth by providing soluble inorganic nutrients and producing growth-promoting factors (Strzelczyk and Pokojska-Burdziej, 1984; Arshad and Frankenberger, 1988; O'Sullivan and O'Gara, 1992; van Rhijn and Vanderleyden, 1995; Spaink et al., 1998; Brimecombe et al., 2007; Nannipieri et al., 2007; Compant et al., 2010). The bacterial diversity and abundance and therefore the type of interactions with the plant root is shaped by the nature of rhizodeposits and soil properties. Rhizodepositions of course vary depending on species and growth stages of the plant, and environmental conditions (Bulgarelli et al., 2013). Soil properties are given e.g., by soil texture, chemical conditions, and moisture; many of them are strongly influenced by seasonal changes (Insam and Seewald, 2010; Bulgarelli et al., 2013). The interplay of all these factors causes a constant dynamic in the rhizo-ecosystem. The role of bacterial volatiles within this continuously changing community still remains mysterious.

Investigating these affairs in such a complex habitat is a challenge. Isolations of bacteria from the rhizosphere, their identifications (Berg et al., 2002), the determination of the volatiles produced (Kai et al., 2007, 2010; von Reuss et al., 2010), and particularly in vitro observations detecting the effects of rhizobacterial volatiles on plants (Ryu et al., 2003, 2004; Vespermann et al., 2007; Wenke et al., 2012) delivered first pieces of the puzzle. However, these data illustrate a dilemma. They have been mostly obtained from artificial and simplified bioassays and test systems, which do not or only partially reflect the complex conditions of the rhizosphere and therefore do not provide sustainable evidence whether microbial volatiles have a substantial impact on bacteria-plant-interactions in the rhizosphere in natura. In order to conceive the complexity of these interactions, additional experimental setups are needed to approach and simulate natural conditions and situations.

In this review, we will summarize currently used techniques and present the corresponding results. We will discuss the benefits, limitations, and pitfalls of these test systems and considering these facts, we would like to introduce ideas for improvements that might provide further insights into the volatile-based bacterial network within the rhizosphere and its implication for plant life.

\section{DIFFERENT TEST SYSTEMS-CONTRASTING EFFECTS}

The first documentation of bacterial volatile-mediated effects on plants was published by Cook and Stall (1969). It took more than 30 years until 2003 Ryu and coworkers seized the issue again and since then different test systems were used by different working groups. Table 1 gives an overview of all experimental systems that have been published so far. These systems can be characterized as follows: (i) setups that used passive diffusion or a directed airflow in order to transport the volatiles to the plant, (ii) target organs were the aerial parts of the plant or the roots, (iii) test system operating with an open or closed loop, and (iv) bacteria growing on different nutrients and matrices. Various combinations of these experimental setups were used. Up to now, in more than half of all existing studies the assays were operated with passive diffusion using divided Petri dishes (Table 1).

\section{Passive Diffusion Systems Closed Systems}

The split Petri dish is a simple and the most favored system (Figure 1A). A barrier separates the dish into two or three compartments to ensure a physical separation of rhizobacteria and plants. The exchange of metabolites is facilitated solely via headspace. Primary target of volatiles is the aerial part of a plant. In order to prevent the escape of volatile metabolites, the Petri dishes were sealed with parafilm. This way, Ryu et al. (2003) could show that volatile compounds produced by plant growth promoting rhizobacteria dramatically increased the leaf surface area of Arabidopsis thaliana seedlings. The entire mixture of volatile metabolites as well as the fermentation products acetoin and $2 \mathrm{R}, 3 \mathrm{R}$-butanediol were shown to be responsible for this effect (Ryu et al., 2003). Both substances were found to trigger induced systemic resistance (Ryu et al., 2004). The data of Han et al. (2006) supported these results. An increase of the total leaf area of $A$. thaliana seedlings was also evident in experiments of Zhang et al. (2007), who additionally showed an influence of rhizobacterial volatiles on auxin homeostasis and cell expansion. Growth promotion was also observed in experiments with sealed split Petri dishes conducted by Banchio et al. (2009); Kai and Piechulla (2009); Ezquer et al. (2010); Kai and Piechulla (2010); Zou et al. (2010); Blom et al. (2011a,b); and Park et al. (2015). A variation of the sealed Petri dish setup is represented by systems that use a box-in-box strategy (Figure 1C). A little container like a glass vial or a Petri dish inoculated with bacteria was placed in a big sealed container hosting the plants. Xie et al. (2009); Banchio et al. (2009); and Ezquer et al. (2010) employed this method. In all experiments, plant growth promotion was observed.

\section{Open Systems}

Omitting the parafilm changed the Petri dish setup toward an open system, which had a distinct impact on the test conditions (Figure 1A). Volatile compounds do not accumulate inside the compartments, which interestingly caused a dramatic growth inhibition of $A$. thaliana (Vespermann et al., 2007; Kai et al., 2008; Wenke et al., 2012; Weise et al., 2013). Kai and Piechulla (2010) directly compared the sealed and unsealed Petri dish system using the moss Physcomitrella patens. They showed that in cocultivation with Serratia plymuthica, the moss gained biomass in sealed systems, while in open systems it suffered a dramatic loss.

In additional experiments (Supplementary Table 1, Velázquez-Becerra et al., 2011; Orozco-Mosqueda et al., 2013; Bailly et al., 2014; Zamioudis et al., 2015), it unfortunately remained unclear whether an open or closed system had been used. However, it should been mentioned that the plant growth was promoted in these studies. Only Bailly et al. (2014) showed growth inhibition using Pseudomonas strains, which was attributed to bacterial $\mathrm{HCN}$ production.

\section{Systems Targeting the Roots}

In order to simulate natural conditions, Park et al. (2015) placed a Pseudomonas fluorescens culture in a plastic container 


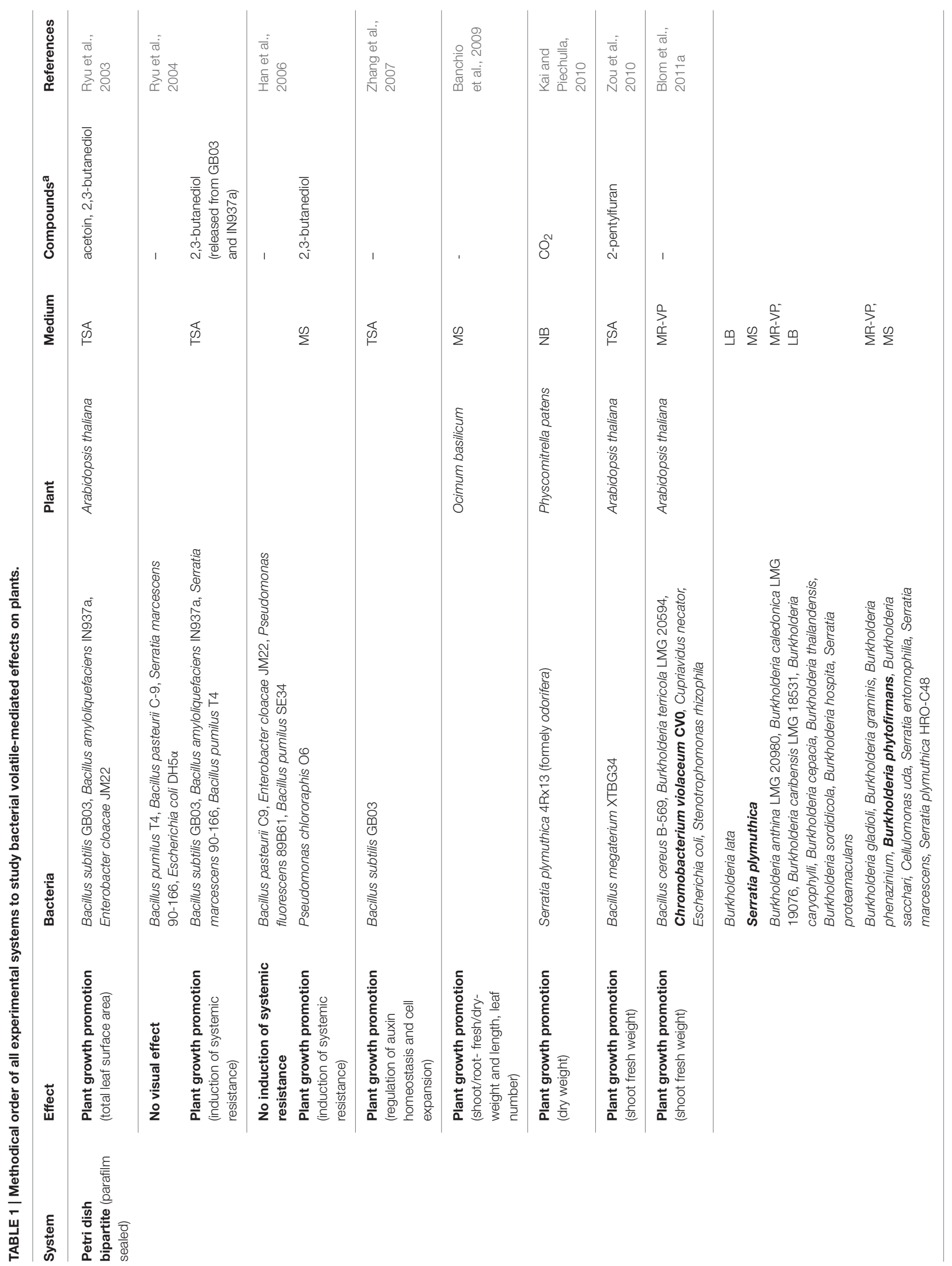




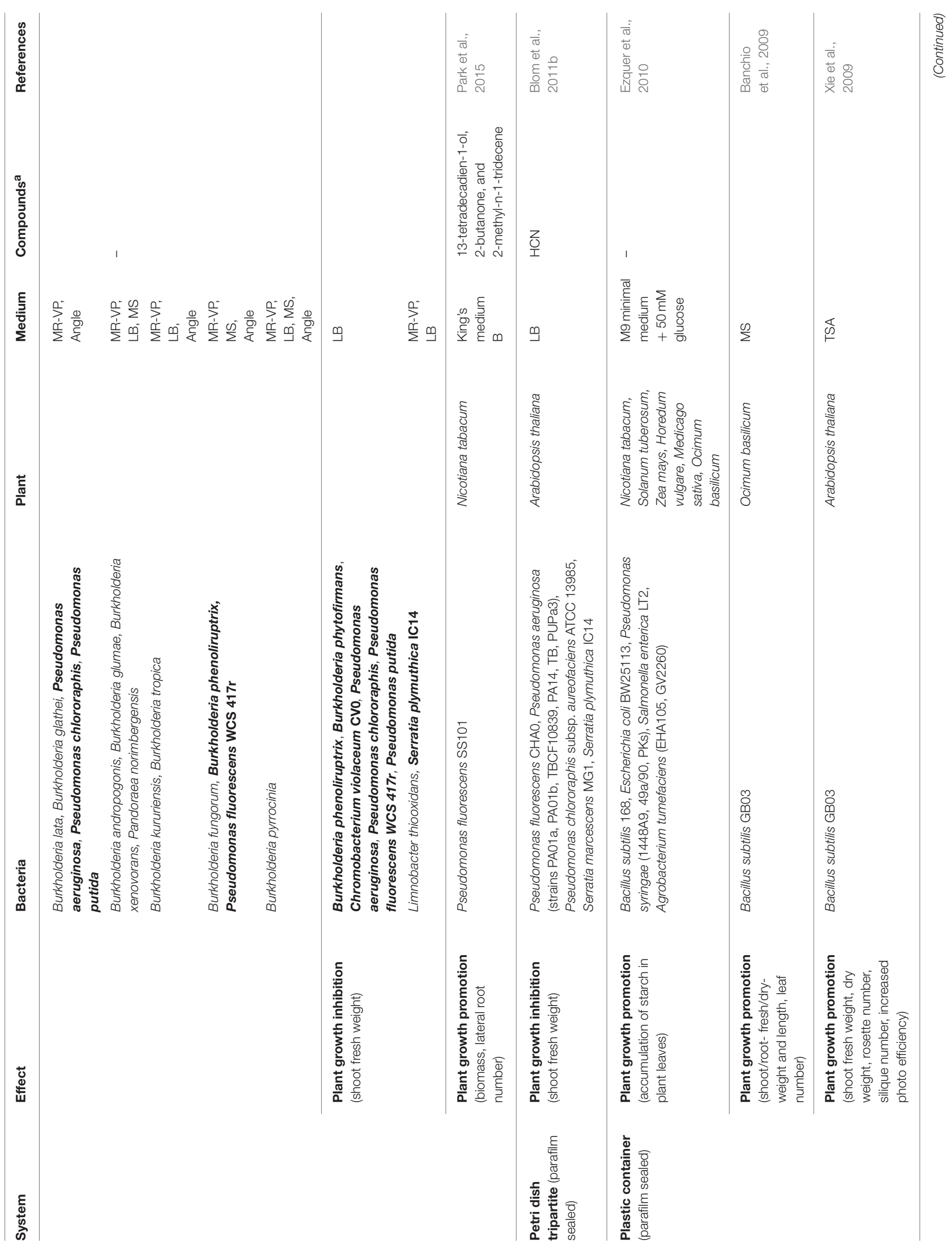




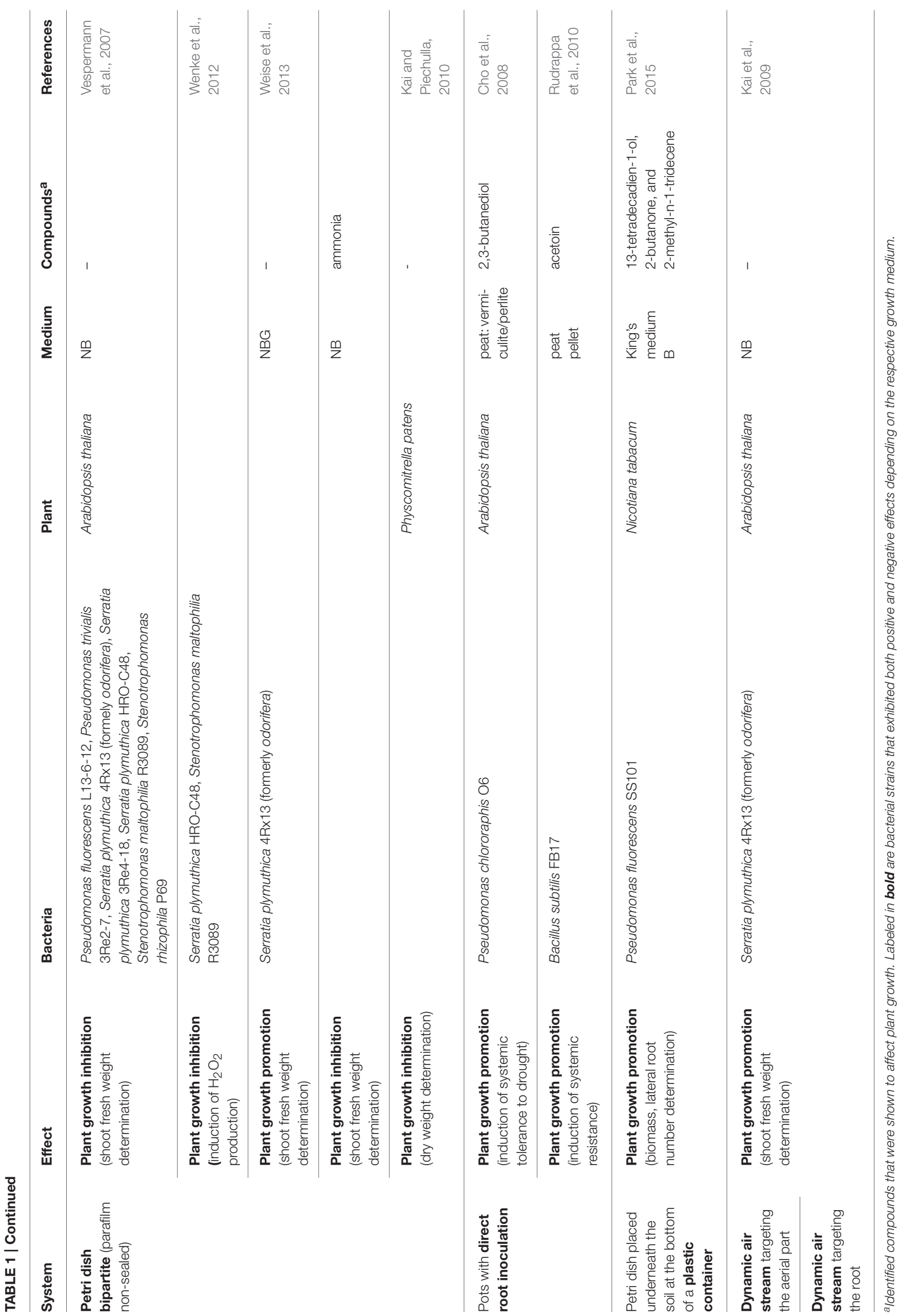



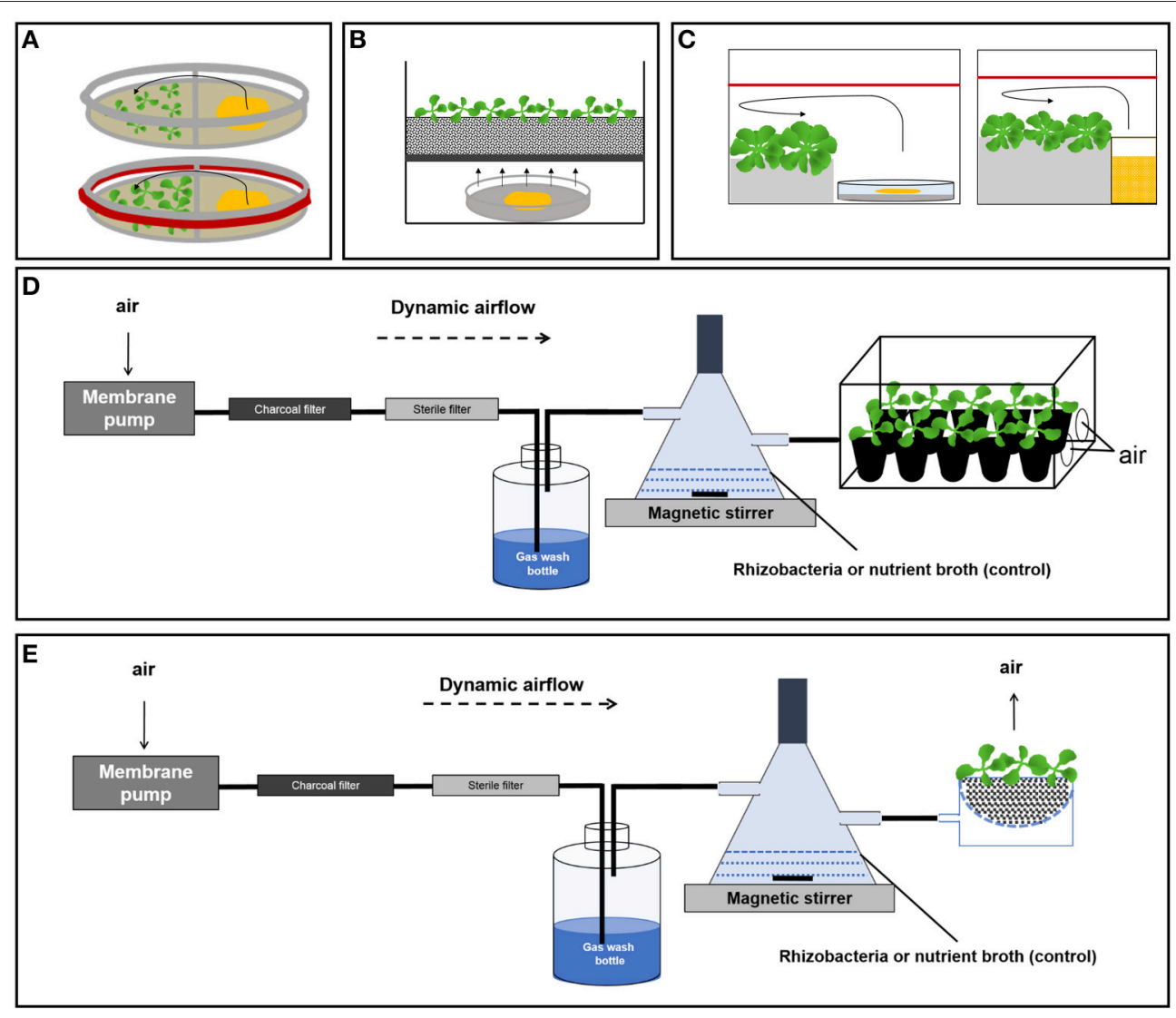

FIGURE 1 | Different bacterial volatile test systems. (A) Passive diffusion in the Petri dish system (upper panel: open system, lower panel: closed system). (B) Passive diffusion targeting the roots. (C) Passive diffusion in container systems useful for older and bigger plants targeting the aerial plant parts (left: bacteria grown on Petri dishes, right: bacteria grown in liquid nutrient medium). (D) Dynamic air stream system targeting the aerial plant parts. (E) Dynamic air stream system targeting the roots.

underneath a defined soil compartment containing growing A. thaliana seedlings (Figure 1B). Bacterial volatiles passively spread and diffused into the soil. After 3 weeks of cultivation, the authors observed significant growth stimulation with an increase of fresh weight of $A$. thaliana.

Another approach was introduced by Cho et al. (2008) and Rudrappa et al. (2010). Roots of A. thaliana seedlings were inoculated with a suspension of Pseudomonas chlororaphis and Bacillus subtilis, respectively. This direct contact of bacteria with the root system did not exclude the influence of non-volatile bacterial metabolites, however, it was shown that the volatile metabolite 2R,3R-butanediol produced by $P$. chlororaphis triggered the induction of systemic tolerance to drought, and acetoin emitted by $B$. subtilis induced systemic resistance.

\section{Dynamic Air Stream Systems}

A dynamic streaming system was used by Cook and Stall (1969). A consistent flow of purified air passed over several bacteria containing agar plates and subsequently reached the aerial part of plants such as Capsicum sp., Nicotiana sp., Lycopersicum sp., and Brassica sp. The volatile mixtures of Xanthomonas vesicatoria, Xanthomonas campestris, Xanthomonas phaseoli, Erwinia carotovora, Erwinia amylovora, Pseudomonas cichorii, Pseudomonas tabaci, and P. fluorescens induced necrosis in leaves of respective plants, whereby $X$. vesicatoria volatiles even killed Capsicum annum. Based on these results, it was assumed that volatiles might be associated with the hypersensitive response in plants (Cook and Stall, 1969).

Kai and Piechulla (2009) compared dynamic air stream systems that targeted (i) the aerial part as well as (ii) the roots of adult $A$. thaliana plants. They reported a considerable growth stimulation and increase in biomass. For system (i), they used a "mini" greenhouse for plant propagation (Figure 1D). Air enriched with volatiles of $S$. plymuthica grown in liquid culture was directed through the headspace of the growth container. For setting up system (ii), a glass bowl with a perforated base holding the plants was precisely positioned over a second glass bowl, which was designed to form a lower compartment equipped with an air inlet. Air enriched with volatile metabolites of $S$. plymuthica entered the lower compartment and escaped via the upper bowl through the soil thereby passing the roots of the plants (Figure 1E). 


\section{IN VITRO TEST SYSTEMS - PITFALLS AND LIMITATIONS}

\section{The Experimental System Matters}

The overview of test systems (Table 1) illustrated a correlation between the setup and the outcome of the experiment. The most apparent difference was observed between closed and open compartment systems. This became most obvious considering the Petri dish systems. Studies using non-sealed plates revealed plant growth inhibition whereas almost all studies with sealed systems resulted in plant growth promotions. Solely, Pseudomonas strains were able to kill plants under both conditions. A split Petri dish setup is simple, inexpensive, easy to handle, allows a high throughput of samples, and assures a physical separation of producer and receiver. Besides these advantages, however, this test system suffers from some disadvantages. Sealing leads to an accumulation of metabolites even up to non-physiological/non-natural concentrations ultimately changing the micro-environment of the compartment and subsequently modifying the metabolism of the test organisms. Most prominent is the accumulation of $\mathrm{CO}_{2}$ due to the bacterial metabolism (Kai and Piechulla, 2009) and the elevated level of humidity due to transpiration of plants (Tholl and Röse, 2006). The $\mathrm{CO}_{2}$ content in the Petri dish can increase up to 10-fold compared to ambient concentrations; which most likely support plant growth in sealed Petri dishes (Kai and Piechulla, 2009). Non-sealed Petri dish systems avoid this accumulation, thus providing a completely different micro-environment.

Another aspect should be considered when the Petri dishes are used. The headspace is limited and therefore only young plant seedlings can be sampled. Their metabolism differs from that of adult plants (Jones et al., 2009). The model plant $A$. thaliana was often investigated, because of its small size, its short life cycle and the availability of myriads of mutants. For other test plants like Nicotiana tabacum, Solanum tuberosum, Zea mays, Hordeum vulgare, Medicago sativa, and Ocimum basilicum and for attempts to use adult plants, bigger growth containers were designed (box systems).

Common to both systems is the fact that the volatile metabolites are released into the headspace and subsequently primarily the aerial parts of the plants are exposed to bacterial volatiles (Figures 1A-D). The habitat of interest, however, is the part of the plant that grows underground. It may be argued that bacterial volatiles diffuse into the agar to target the roots, however, only rather hydrophilic volatiles permeate into the hydrophilic agar, while the lipophilic nature of most volatile metabolites obstructs a passage into the agar. Furthermore, compartmentalized systems, especially Petri dishes, do not meet different physiological demands of the test organisms. Despite the fact that the rhizosphere is a dark environment, bacteria as well as plant roots are exposed to light in the used experimental setups (Figures 1A-E).

Technical solutions that resolve some of these constraints allow a direct application of rhizobacterial volatiles to the roots (Cho et al., 2008; Kai and Piechulla, 2009; Rudrappa et al.,
2010; Park et al., 2015). However, persistent in all systems is the fact that the production of rhizobacterial volatile metabolites strongly depends on the nutrient source. Already, Cook and Stall (1969) observed a nutrient-dependent effect, since only bacteria grown on nutrient agar (NA) or Kings B medium (KBM) caused necrosis in leaf tissues. Blom et al. (2011a) comprehensively investigated the influence of bacteria grown on different media. Subsequently they observed altered and contrasting effects on plant growth. The deleterious effect was caused by HCN produced by Pseudomonas strains grown on protein rich media (LB agar; Blom et al., 2011b). The principle of this finding was also supported by Weise et al. (2013). S. plymuthica produced $\mathrm{NH}_{3}$ only on protein enriched nutrient agar. This caused plant growth inhibition in open Petri dish systems whereas in sealed systems plant growth was promoted (Kai and Piechulla, 2009). Plants in unsealed systems were harmed by gaseous $\mathrm{NH}_{3}$ itself, due to plant medium alkalization and/or $\mathrm{NH}_{4}^{+}$toxicity (Weise et al., 2013). In sealed dishes, the high $\mathrm{CO}_{2}$ concentration might promote formation of acidic $\mathrm{HCO}_{3}^{+}$thereby preventing alkalization and consequently growth inhibition.

These examples show that compartment systems and especially split Petri dishes develop very fragile and vulnerable micro-environments for both bacteria and plants. This has to be considered when interpreting the results. In summary, different test conditions hamper a direct comparison of the results obtained. However, every setup represents a valuable test system that contributed to the overall picture of bacteria-plantinteractions.

\section{Soil Matters}

While the adherence of bacteria to the rhizoplane seems to be supported by biofilm formation (Rudrappa et al., 2008; ReinholdHurek et al., 2015), the growth of bacteria and the fate of volatiles within the rhizosphere depend considerably on soil conditions (Effmert et al., 2012; Burns et al., 2015). In most experimental setups, bacteria were grown on artificial medium such as solid agar or liquid media. Although these media might be vaguely reminiscent of biofilm substrates or water filled pores, so far the influence of physicochemical properties of soil has been neglected in most experimental approaches. This involves the influence of soil on the bacterial life as well as the production and distribution of bacterial volatiles. Solely direct inoculations of bacteria (Cho et al., 2008; Rudrappa et al., 2010) and purging of volatile enriched air into the soil (Kai and Piechulla, 2009; Park et al., 2015) to some extent considered effects of the natural underground habitat.

\section{Ecological Relevance of Rhizobacterial Volatiles-Quality and Quantity Matter}

In many experimental setups, bacteria were inoculated into artificial media. These mostly nutrient rich conditions directed the metabolic activity of bacteria and thereby influenced the quality and quantity of the volatile metabolite synthesis. A nutrient enriched zone is in fact present on the root surface where root-derived organic compounds attract a diverse and 
specialized bacterial community. Nutritional conditions in more distant areas from roots might be different resulting in an altered microbial community (Garbeva et al., 2014; Reinhold-Hurek et al., 2015). Regarding this aspect, in vitro concentrations and the quality of the mixture of bacterial volatiles should be critically examined.

\section{Cell Numbers Matter (True Controls Matter)}

An important aspect is whether the influence of bacteria on plant growth is a specific or a general phenomenon. Most studies present bacterial strains without any effect on plant growth as a corresponding negative control; e.g., the laboratory strain E.coli DH5 $\alpha$. However, due to different metabolic abilities to grow under the same nutritional conditions the growth rate and subsequently the concentration of volatile released differ between test and control strains. Images of split Petri dish setups of several studies illustrate these differences. Thus, volatiles produced by the control strain might be simply below the minimal affective concentration, e.g., different bacterial spot sizes implicating different bacterial growth rates (Ryu et al., 2003; Han et al., 2006; Kai et al., 2008; Zou et al., 2010; Blom et al., 2011a; Park et al., 2015). Bailly and Weisskopf (2012) already discussed this issue and assumed cell number dependent effects on plant growth. At a certain time point, slow and fast growing bacterial species appear in different growth phases thereby influencing the plant growth in different ways. Experiments performed by Blom et al. (2011a) confirmed this assumption. In addition, different cell densities might influence the regulation of the production of volatiles via quorum sensing (Kesarwani et al., 2011). As a consequence, the initial cell numbers of different bacterial species especially those of test and control strains should be adjusted as well as final cell numbers need to be determined and compared.

\section{Interactions Matter}

The physical separation of bacteria and plants represents an ambiguous aspect of setups that have been used so far. It allows for an exclusive investigation of effects of volatile-mediated interactions. Intra- and interspecific interactions, however, represent an intrinsic characteristic of the rhizosphere (Burns et al., 2015). The spectrum of bacterial volatiles will be influenced and even altered by bacterial and/or plant metabolites such as root exudates, infochemicals, or antibiotics, which do not have to be necessarily volatile. These metabolites might be continuously or only upon interaction produced and secreted. Interactioninduced allelochemical production and allelochemical-induced production of bacterial volatiles represent one of the most interesting aspects of rhizosphere investigations (Garbeva et al., 2011, 2014; Hol et al., 2015; Schulz-Bohm et al., 2015). The simulation of rhizodeposition might be realized by a defined nutrient composition of the bacterial medium (Blom et al., 2011a; Garbeva et al., 2014; Schulz-Bohm et al., 2015); the influence of allelochemicals on bacterial volatile production and the consequences for plant-bacterial interaction still awaits a substantial investigation.

\section{CHARACTERISTICS OF THE HABITAT-KEY DEMANDS FOR NOVEL EXPERIMENTAL SETUPS}

In vitro test systems used so far are indispensable to get first insights into volatile-mediated effects of rhizobacteria on plants. Nevertheless, refined systems and novel approaches are necessary to dig deeper into the precise mechanisms of volatilebased bacteria-plant-interactions. Adequate experimental setups should really mimic or simulate as closely as possible rhizosphere conditions. These conditions shape evolving microbial communities and consequently the quality and quantity of volatiles. At the same time, the rhizosphere represents the matrix that determines the fate of volatile metabolites and facilitates or limits their diffusion. Matrix properties include the soil properties, chemical conditions $(\mathrm{pH}$, aeration), and environmental factors (temperature, water content, darkness; Voroney and Heck, 2015). Traits that particularly influence the microbial communities are the nutrient status (root exudates, trace elements) and the interplay within the microbial community/population. The following section will briefly highlight these characteristics that have to be considered in order to develop suitable novel experimental setups.

\section{Soil Properties, Chemical Parameters, and Environmental Factors}

Soil is an aggregation of inorganic and organic particles, whereby the inorganic material is glued together with the organic matter (Voroney and Heck, 2015). The particle size of the inorganic particles varies between 0.002 and $2 \mathrm{~mm}$ resulting in different soil components including clay (below $0.002 \mathrm{~mm}$ ), silt $(0.05-$ $0.002 \mathrm{~mm})$, and sand $(2-0.05 \mathrm{~mm})$. The proportion of the three components determines the soil texture. Aggregates of the soil minerals of different size and organic materials cluster together forming the soil structure. About 35\% (mineral soils) up to $90 \%$ (organic soils) of a soil volume can be taken up by pore space. Hereby, soil pores with a diameter below $10 \mu \mathrm{m}$ (micropores) are important for the aqueous environment of bacteria, while soil pores below $5 \mu \mathrm{m}$ in diameter are not colonized by microorganisms most likely due to impaired diffusion of nutrients. However, the gaseous diffusion and more specifically the diffusion of volatiles into micropores is supposed to be slow because of the water content. In contrast, macropores (diameter $>10 \mu \mathrm{m}$ ) facilitate rapid air and volatile diffusion. Effects of volatiles mediated over short distances should involve micropores, whereas effects over long distances probably require macropores. Furthermore, size and shape of pores determine their water and/or air content. Water is the universal factor in the rhizosphere influencing soil aeration, moisture, osmotic pressure, and $\mathrm{pH}$ or nature and amount of soluble substances available to or affecting organisms. While for soluble compounds water represents a perfect medium of transportation, it hampers diffusion of volatile metabolites due to their lipophilic nature. Aeration, which is driven by diffusion between the atmosphere and soil, again, promotes the emanation of volatiles. Diffusion through air filled pores is 10,000 times better than through water 
filled pores (Voroney and Heck, 2015). Closely connected to soil aeration is the availability of molecular oxygen $\left(\mathrm{O}_{2}\right) \cdot \mathrm{O}_{2}$ belongs to the most crucial factors for aerobic activity in soil. Due to the lower diffusion distance compared to the atmosphere, the partial pressure $\left(\mathrm{pO}_{2}\right)$ in the topsoil is higher compared to the deeper regions (Glinski and Stepniewski, 1985; Stepniewski and Stepniewska, 2009) and considering soil aggregates, the $\mathrm{pO}_{2}$ diminishes from the outside to the center where even anoxic states are obtained (Sexstone et al., 1985; Zausig et al., 1993). The $\mathrm{pO}_{2}$ in the rhizosphere, depends on respiration processes and the diffusive $\mathrm{O}_{2}$ replenishment (Glinski and Stepniewski, 1985; Uteau et al., 2015). The respective oxygen status is the factor that clinches the switch from aerobic to anaerobic respiration in soil which fundamentally influences the metabolome and hence the volatile production. The fluctuation of temperature has to be considered as another fundamental factor of influence. Every organism has its own temperature optimum (Farrell and Rose, 1967). Bacteria, of course, can adapt to fluctuating temperatures, but this might be coupled with alterations of metabolism of the respective organisms, which may also lead to a different profile of volatiles. Furthermore, when temperatures reached threshold levels, for instance for mesophilic and thermophilic bacteria, the species diversity and abundance of communities shifted (Leven et al., 2007). Seasonally and/or diurnally changing temperatures should be therefore taken into account when natural conditions should be simulated (Voroney and Heck, 2015). Temperature, however, influences not only organisms. The decrease of temperature can cause an attenuated evaporation and diffusion of volatile molecules in the soil. The online screening of the soil/atmosphere exchange of volatiles conducted by Asensio et al. (2007) showed that the emission of some soil VOCs was enhanced due to increased soil temperatures.

\section{Nutritional Conditions, Bacterial Growth, and Developmental Stages}

Nutrient conditions within the rhizosphere are primarily regulated by the plants exuding excess photosynthetic products through the roots into the soil (Barber and Martin, 1976; Lynch and Whipps, 1991; Marschner, 1995; Hütsch et al., 2002). Thereby, the relative and absolute amounts of plant-derived nutrients in the rhizosphere vary with the plant species, plant age, and environmental conditions the plant has to cope with (e.g., soil properties, biotic, and abiotic stresses). Rhizodeposits include sugars, polysaccharides, amino acids, organic acids, fatty acids, and sterols (reviewed in Uren, 2007). Unfortunately, exudation of rhizodeposites was mostly studied in vitro on media other than soil, and therefore the in vivo exudation status of the rhizosphere and its change in time remains speculative (Uren, 2007). However, Bulgarelli et al. (2013) impressively showed that a variation of rhizodeposits caused an alteration of the plant root microbiome implicating a very dynamic production of bacterial volatiles. Besides this nutritional influence it can be assumed that due to bacterial growth and different developmental stages the bacterial metabolism and subsequently the formation of volatiles is changing. The production and effects of volatiles in dependence on bacterial developmental factors as well as growth stages, the formation of biofilms, generation of spores, or movement factors like swimming and swarming has so far not been in focus of the current research.

\section{Bacterial Interactions in the Rhizosphere}

Bacterial interactions in the rhizosphere occur in three directions, (i) interaction of the bacteria with the plant (Bais et al., 2006; Rudrappa et al., 2008; Bednarek and Osbourn, 2009), (ii) the intra- and interspecific communication within the bacterial community (Ryan and Dow, 2008; Shank and Kolter, 2009; Garbeva et al., 2011; Tyk et al., 2014), and (iii) interaction with protozoa and metazoa (Matz and Kjelleberg, 2005; Ronn et al., 2012).

Plants release plenty of secondary metabolites, e.g., terpenes, flavonoids, glucosinolates, and phenylpropanoids into the rhizosphere (Dixon and Paiva, 1995; Rasmann et al., 2005; Van Dam et al., 2009; Bressan et al., 2009; Moore et al., 2014). Minor modifications in secondary metabolite level can have an important impact on soil microbial communities (Bressan et al., 2009). Flavonoids for instance are able to mimic quorum sensing (QS) molecules and thereby influencing the bacterial metabolism (Hassan and Mathesius, 2012). The production of 2-aminoacetophenone, a volatile metabolite produced by Pseudomonas aeruginosa, Streptomyces spp., and Burkholderia ambifaria is known to be QS regulated (Cox and Parker, 1979; Dickschat et al., 2005; Kesarwani et al., 2011; Groenhagen et al., 2013). Since it is predicted that many more volatiles are QS regulated, it is assumed that the interplay between plants and bacteria can change the pattern of volatile emission of bacteria. Thus, the QS system that controls basic processes of the bacterial life (e.g., biofilm formation and motility; Lowery et al., 2008) is likely to also affect the quality and quantity of volatiles. This is particularly important in highly competitive situations between different bacterial organisms that benefit from nutrient rich conditions in the rhizosphere. Moreover, bacteria evolved different strategies of antagonism including the release of antibiotics, lytic enzymes, siderophores, and toxins (Thomashow et al., 1990; O’Sullivan and O'Gara, 1992; Chernin et al., 1995; Pliego et al., 2008; and others). Driven by these manifold antagonistic properties and also due to the competition regarding water, nutrient and space, the bacteria react with the production of own weapons (Abrudan et al., 2015). For instance during interaction, Streptomyces coelicolor induced pigment production and hyphae formation in B. subtilis PY79 and simultaneously B. subtilis PY79 enhanced the production of cannibalism toxins in S. coelicolor (Watrous et al., 2012). In addition to antagonistic action also cooperation might affect emission of volatile metabolites. Metabolome profiling revealed that $B$. megaterium and Ketogulonicigenium vulgare cooperated by exchanging a number of metabolites (Zhou et al., 2011). This exchange increased the pool of own metabolites and hence different potential precursors of volatiles were available for the cooperating strains. It is therefore conceivable that the emission of volatiles might also alter due to bacteria-bacteria interaction. First data supporting this assumption were presented by Hol et al. (2015) and Schulz-Bohm et al. (2015). While Hol et al. (2015) showed that a non-random loss in bacteria communities reduced antifungal volatile production, Schulz-Bohm et al. (2015) could 
show that both microbial interactions and shifts in microbial community composition had a strong effect on the volatile emission. Likewise, bacterial interactions with fungi have to be considered. Splivallo et al. (2015) showed impressively that fruiting body associated bacteria contributed to the smell of the truffle Tuber borchii by synthesizing thiophene from a currently unknown precursors produced by $T$. borchii. Furthermore, Schmidt et al. (2015b) showed that Collimonas pratensis and $S$. plymuthica PRI-2C showed significant changes in their motility when exposed to fungal volatiles coming to the conclusion that bacteria are able to sense and respond to fungal volatiles (Schmidt et al., 2015b).

\section{FUTURE TEST SYSTEMS}

Considering the complexity of the rhizosphere, it is eligible in a first step to use standardized conditions, such as sterilized sand inoculated with a single bacterial isolate or mixtures of bacterial species. Although plant growth on sand does not always reflect the most frequently used soil by plants, it has the advantage that variation in soil structure is limited compared to other soils. After these initial studies with sand, experimental setups should be approximated to more complex natural soil conditions. The second challenge is to match the diversity of the rhizobacterial community. Here the proposed strategy would be to start with one or a few bacterial species and gradually increase the number and variation of combinations to simulate the rhizosphere situation.

In order to investigate volatile compounds of root associated bacteria and to study their effects on plants, an experimental rhizosphere platform should be designed (Figure 2B). The core of the platform represents a root box equipped with an inlet and an outlet for air exchange (Figure 2A). The leakage of sand particles from the chamber is avoided by perforated barriers between the in- and outlet and the root box. The front plate of the box should be composed of transparent and inert Teflon ${ }^{\circledR}$ or glass material in order to observe root growth by e.g., eye or camera. On top of the box a small opening is the gateway for
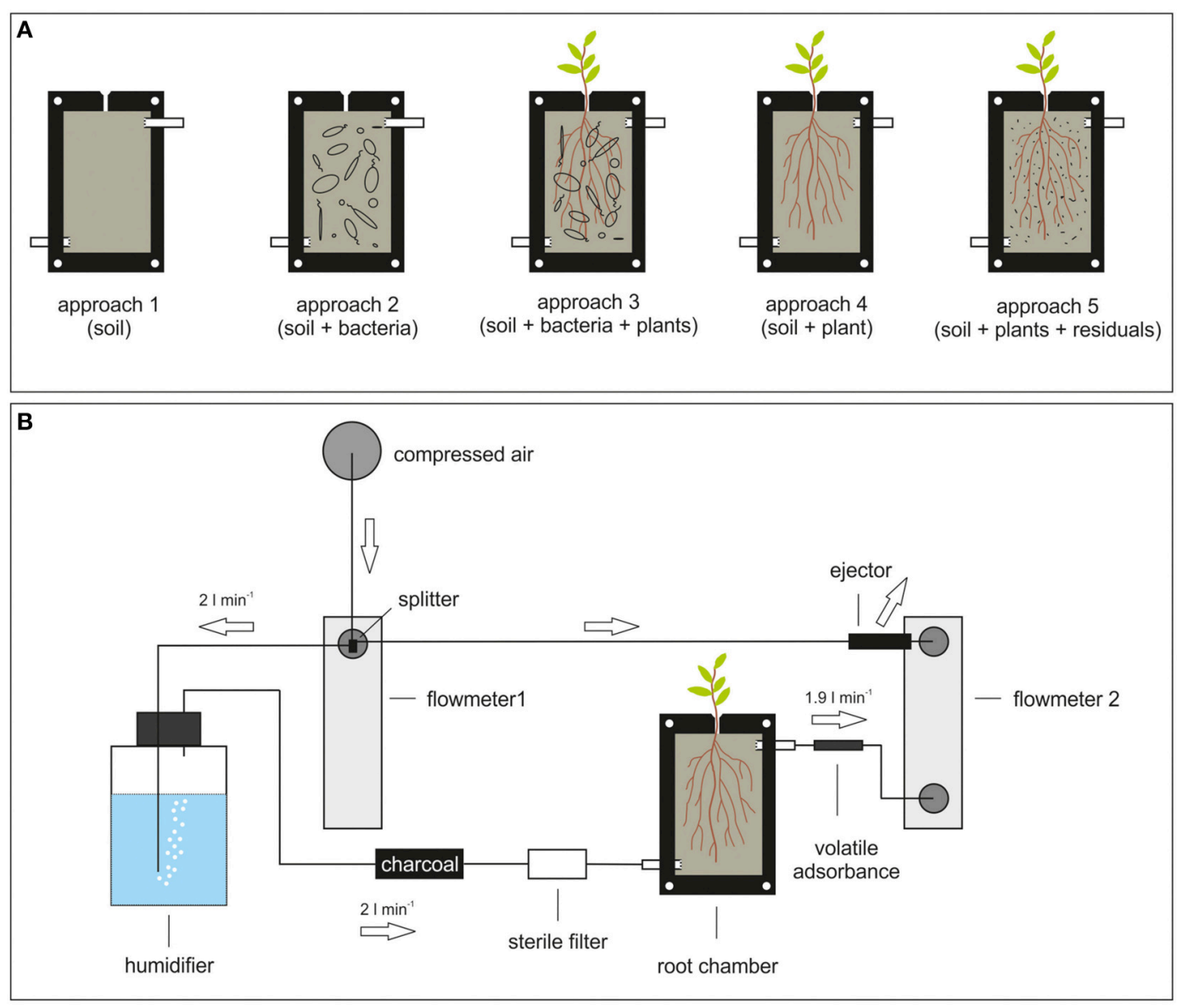

FIGURE 2 | Platform to analyze volatiles and volatile mediated effects. (A) Root chamber. Several approaches are exemplified: 1. soil only; 2. soil and bacteria; 3. soil, bacteria, and plants; 4. soil and plants; 5. soil and bacterial residuals. (B) Design of a volatile-collection system using the root chamber. Arrows indicate direction of airflow. The flow of $2 \mathrm{l} / \mathrm{min}$ is exemplary indicated, since it always depends on the kind of adsorbent used. The splitter is separating the incoming airflow. On one site the air is humidified (gas washing bottle), and purified (charcoal and sterile filter) before passing into the root chamber. On the other site the ejector reverses the airflow that the volatile enriched air is pulled out of the root chamber over an adsorbent trap. 
plant roots expanding into the box. The space inside the box can be filled with the matrix of choice regarding texture and composition. Before starting the experiment, the box as well as the matrix will be sterilized by gamma- or UV radiation, or by autoclaving. Surface sterilized seeds would be placed at the top puncture of the root box and upon germination the roots will push their way through the hole and develop their root network into the matrix.

The advantage of this setup is the possibility of arbitrary co-cultivation and co-development of (various) bacterial species with the plant root. The correct assignment of emitted volatiles either to the plant root or bacterial species has to be performed by differential analysis of the several setups (soil only, bacteria only, plant only, bacteria, and plant and so on; Figure 2A). Beside the characterization of plant growth parameter (shoot- and root fresh weight, plant omics) under various different conditions, a continuous measurement of volatile emission of appropriate time intervals can be established. Thereby, it should be distinguished between volatiles that bind to soil particles or aggregates by using in situ polydimethylsiloxane micro-extraction (Eilers et al., 2015) and volatiles that do not bind to soil by passing air through the root box and further over an adsorbent trap (Figure 2B). The above mentioned differential analysis would provide information about plant growth in combination with data about the status of volatiles in the root system. A similar approach was introduced by Eilers et al. (2015) originally developed for Dandelion (Taraxacum sect. ruderalia) root volatiles. This system aimed to simply and inexpensively detect rhizosphere chemicals at experimentally less disturbed conditions. Therefore, it could be adapted in order to use it for bacteria-plant interaction. Nevertheless, since the assignment of volatiles to the producer in these systems is still difficult, there is a need to verify specificity of volatile-mediated effects by evaluating the obtained data in the compartmented test systems in vitro. These verifications must include the check for profiles of bacterial volatiles as well as the application of single compounds/mixtures of volatiles. Such a combinatory approach of the different test systems and

\section{REFERENCES}

Abrudan, M. I., Smakman, F., Grimbergen, A. J., Westhoff, S., Miller, E. L., van Wezel, G. P., et al. (2015). Socially mediated induction and suppression of antibiosis during bacterial coexistence. Proc. Natl. Acad. Sci. U.S.A. 112, 11054-11059. doi: 10.1073/pnas.1504076112

Arshad, M., and Frankenberger, W. T. Jr. (1988). Influence of ethylene produced by soil microorganisms on etiolated pea seedlings. Appl. Environ. Microbiol. 54, 2728-2732.

Asensio, D., Penuelas, J., Filella, I., and Llusia, J. (2007). On-line screening of soil VOCs exchange responses to moisture, temperature and root presence. Plant Soil 291, 249-261. doi: 10.1007/s11104-006-9190-4

Audrain, B., Farag, M. A., Ryu, C-M., and Ghigo, J-M. (2015). Role of bacterial volatile compounds in bacterial biology. FEMS Microbiol. Rev. 39, 222-233. doi: 10.1093/femsre/fuu013

Bailly, A., Groenhagen, U., Schulz, S., Geisler, M., Eberl, L., and Weisskopf, L. (2014). The inter-kingdom volatile signal indole promotes root development by interfering with auxin signalling. Plant J. 80, 758-771. doi: 10.1111/tpj. 12666 techniques will help to understand the volatile-mediated effects on plant growth.

\section{CONCLUSIONS}

Recent advances have enhanced our understanding that small volatile molecules emitted by bacteria can have dramatic effects on the growth and development of plants. These observations were mainly based on various different experimental setups, often revealing discrepancies between results. In addition, most test systems neglected properties and complexity of the rhizosphere. In order to go beyond the search for potential effects and to evaluate the significance of rhizobacterial volatiles in situ, setups that mimic the rhizosphere, that allow for a combination of various bacterial species and if desired other microorganisms, that assure for the usage of different soil matrices, and that enable in situ-volatile collections, the root box embedded into the so called rhizosphere platform could be considered to be a first step into this direction.

\section{AUTHOR CONTRIBUTIONS}

MK designed research; MK, UE, and BP wrote the paper.

\section{ACKNOWLEDGMENTS}

We are thankful for suggestions of Daniel Veit concerning the volatile collection system.

\section{SUPPLEMENTARY MATERIAL}

The Supplementary Material for this article can be found online at: http://journal.frontiersin.org/article/10.3389/fmicb. 2016.00108

Supplementary Table 1 | Investigations in which remained unclear whether an open or closed system had been used. ${ }^{1}$ Identified compounds that were shown to affect plant growth.
Bailly, A., and Weisskopf, L. (2012). The modulating effect of bacterial volatiles on plant growth: current knowledge and future challenges. Plant Signal. Behav. 7, 79-85. doi: 10.4161/psb.7.1.18418

Bais, H. P., Weir, T. L., Perry, L. G., Gilroy, S., and Vivanco, J. M. (2006). The role of root excudates in rhizosphere interactions with plants and other organisms. Annu. Rev. Plant Biol. 57, 233-266. doi: 10.1146/annurev.arplant.57.032905.105159

Banchio, E., Xie, X., Zhang, H., and Paré, P. W. (2009). Soil bacteria elevate essential oil accumulation and emissions in sweet basil. J. Agr. Food Chem. 57, 653-657. doi: 10.1021/jf8020305

Barber, D. A., and Martin, J. K. (1976). The release of organic substances by cereal roots into soil. New Phytol. 76, 69-80. doi: 10.1111/j.1469-8137.1976. tb01439.x

Bednarek, P., and Osbourn, A. (2009). Plant-microbe interactions: chemical diversity in plant defense. Science 324, 746-748. doi: 10.1126/science.1171661

Berg, G., Roskot, N., Steidle, A., Eberl, L., Zock, A., and Smalla, K. (2002). Plantdependent genotypic and phenotypic diversity of antagonistic rhizobacteria isolated from different Verticillium host plants. Appl. Environ. Microbiol. 68, 3328-3338. doi: 10.1128/AEM.68.7.3328-3338.2002 
Bitas, V., Kim, H-S., Bennett, J. W., and Kang, S. (2013). Sniffing on microbes: diverse roles of microbial volatile organic compounds in plant health. Mol. Plant Microbe Interact. 26, 835-843. doi: 10.1094/MPMI-10-12-0249-CR

Blom, D., Fabbri, C., Connor, E. C., Schiestl, F. P., Klauser, D. R., Boller, T., et al. (2011a). Production of plant growth modulating volatiles is widespread among rhizosphere bacteria and strongly depends on culture conditions. Environ. Microbiol. 13, 3047-3058. doi: 10.1111/j.1462-2920.2011. 02582.x

Blom, D., Fabbri, C., Eberl, L., and Weisskopf, L. (2011b). Volatile-mediated killing of Arabidopsis thaliana by bacteria is mainly due to Hydrogen Cyanide. Appl. Environ. Microbiol. 77, 1000-1008. doi: 10.1128/AEM.01968-10

Bressan, M., Roncato, M-A., Bellvert, F., Comte, G., Zahar Haichar, F., Achouak, W., et al. (2009). Exogenous glucosinolate produced by Arabidopsis thaliana has an impact on microbes in the rhizosphere and plant roots. ISME J. 3, 1243-1257. doi: 10.1038/ismej.2009.68

Brimecombe, M. J., De Leij, F. A. A. M., and Lynch, J. M. (2007). "Rhizodeposition and microbial populations," in The Rhizosphere: Biochemistry and Organic Substances at the Soil-Plant Interface, eds R. Pinton, Z. Varanini, and P. Nannipieri (New York, NY: Marcel Dekker), 41-93.

Bulgarelli, D., Schlaeppi, K., Spaeten, S., Ver Loren van Themaat, E., and SchulzeLefert, P. (2013). Structure and functions of the bacterial microbiota of plants. Annu. Rev. Plant Biol. 64, 807-838. doi: 10.1146/annurev-arplant-050312120106

Burns, J. H., Anacker, B. L., Strauss, S. Y., and Burke, D. J. (2015). Soil microbial community variation correlates most strongly with plant species identity, followed by soil chemistry, spatial location and plant genus. AoB Plants 7:plv030 doi: 10.1093/aobpla/plv030

Chernin, L., Ismailov, Z., Haran, S., and Chet, I. (1995). Chitinolytic Enterobacter agglomerans antagonistic to fungal plant pathogens. Appl. Envir. Microbiol. 61, 1720-1726.

Cho, S. M., Kang, B. R., Han, S. H., Anderson, A. J., Park, J. Y., Lee, Y. H., et al. (2008). 2R,3R-butanediol, a bacterial volatile produced by Pseudomonas chlororaphis $\mathrm{O6}$, is involved in induction of systemic tolerance to drought in Arabidopsis thaliana. Mol. Plant Microbe Interact. 21, 1067-1075. doi: 10.1094/MPMI-21-8-1067

Compant, S., Clément, C., and Sessitsch, A. (2010). Plant growth promoting bacteria in the rhizo- and endosphere of plants: their role, colonization, mechanisms involved and prospects for utilization. Soil Biol. Biochem. 42, 669-678. doi: 10.1016/j.soilbio.2009.11.024

Cook, A. A., and Stall, R. E. (1969). Necrosis in leaves induced by volatile materials produced in vitro by bacteria. Phytopathol. Notes 59, 259-260.

Cox, C. D., and Parker, J. (1979). Use of 2-Aminoacetophenone production in identification of Pseudomonas aeruginosa. J. Clin. Microbiol. 9, 479-484.

Dickschat, J. S., Martens, T., Brinkhoff, T., Simon, M., and Schulz, S. (2005). Volatiles released by a Streptomyces species isolated from the North Sea. Chem. Biodivers. 2, 837-865. doi: 10.1002/cbdv.200590062

Dixon, R. A., and Paiva, N. L. (1995). Stress-induced phenylpropanoid metabolism. Plant Cell 7, 1085-1097. doi: 10.1105/tpc.7.7.1085

Dweck, H. K. M., Ebrahim, S. A. M., Thoma, M., Mohamed, A. A. M., Keesey, I. W., Trona, F., et al. (2015). Pheromones mediating copulation and attraction in Drosophila. Proc. Natl. Acad. Sci. U.S.A. 112, E2829-E2835. doi: 10.1073/pnas.1504527112

Effmert, U., Kalderas, J., Warnke, R., and Piechulla, B. (2012). Volatile mediated interactions between bacteria and fungi in the soil. J. Chem. Ecol. 38, 665-703. doi: 10.1007/s10886-012-0135-5

Eilers, E. J., Pauls, G., Rilig, M. C., Hansson, B. S., Hilker, M., and Reinecke, A. (2015). Novel setup for low-disturbance sampling of volatile and non-volatile compounds from plant roots. J Chem. Ecol. 41, 253-266. doi: 10.1007/s10886015-0559-9

Ezquer, I., Li, J., Ovecka, M., Baroja-Fernández, E., Muñoz, F. J., Montero, M., et al. (2010). Microbial volatile emissions promote accumulation of exceptionally high levels of starch in leaves in mono- and dicotyledonous plants. Plant Cell Physiol. 51, 1674-1693. doi: 10.1093/pcp/pcq126

Farrell, J., and Rose, A. (1967). Temperature effects on microorganisms. Annu. Rev. Microbiol. 21, 101-120.

Garbeva, P., Hordijk, C., Gerards, S., and de Boer, W. (2014). Volatile-mediated interactions between phylogenetically different soil bacteria. Front. Microbiol. 5:289. doi: $10.3389 /$ fmicb. 2014.00289
Garbeva, P., Silby, M. W., Raaijmakers, J. M., Levy, S. B., and De Boer, W. (2011) Transcriptional and antagonistic responses of Pseudomonas fluorescens Pf0-1 to phylogenetically different bacterial competitors. ISME J. 5, 973-985. doi: 10.1038/ismej.2010.196

Glinski, J., and Stepniewski, W. (1985). Soil Aeration and its Role for Plants. Boca Raton, FL: CRC Press.

Groenhagen, U., Baumgartner, R., Bailly, A., Gardiner, A., Eberl, L., Schulz, S., et al. (2013). Production of bioactive volatiles by different Burkholderia ambifaria strains. J. Chem. Ecol. 39, 892-906. doi: 10.1007/s10886-01 3-0315-y

Han, S. H., Lee, S. J., Moon, J. H., Park, K. H., Yang, K. Y., Cho, B. H., et al. (2006). GacS-dependent production of 2R, 3R-butanediol by Pseudomonas chlororaphis O6 is a major determinant for eliciting systemic resistance against Erwinia carotovora but not against Pseudomonas syringae pv. tabaci in Tobacco. Mol. Plant Microbe Interact. 19, 924-930. doi: 10.1094/MPMI-19-0924

Hare, J. D. (2011). Ecological role of volatiles produced by plants in response to damage by herbivorous insects. Annu. Rev. Entomol. 56, 161-180. doi: 10.1146/annurev-ento-120709-144753

Hassan, S., and Mathesius, U. (2012). The role of flavonoids in rootrhizosphere signalling: opportunities and challenges for improving plantmicrobe interactions. J. Exp. Bot. 63, 3429-3444. doi: 10.1093/jxb/err430

Hol, W. H. G., Garbeva, P., Hordijk, C., Hundscheid, M. P. J., Klein Gunnewiek, P. J. A., van Agtmaal, M., et al. (2015). Non-random species loss in bacterial communities reduces antifungal volatile production. Ecology 96, 2042-2048. doi: 10.1890/14-2359.1

Hütsch, B. W., Augustin, J., and Merbach, W. (2002). Plant rhizodeposition an important source for carbon turnover in soils. J. Plant Nutr. Soil Sci. 165, 397-407. doi: 10.1002/1522-2624(200208)165:4<397::AIDJPLN397>3.0.CO;2-C

Insam, H., and Seewald, M. S. A. (2010). Volatile organic compounds (VOCs) in soils. Biol. Fert. Soils 46, 199-213. doi: 10.1007/s00374-010-0442-3

Jones, D. L., Nguyen, C., and Finlay, R. D. (2009). Carbon flow in the rhizosphere: carbon trading at the soil-root interface. Plant Soil 321, 5-33. doi: 10.1007/s11104-009-9925-0

Kai, M., Crespo, E., Cristescu, S. M., Harren, F. J. M., Francke, W., and Piechulla, B. (2010). Serratia odorifera: analysis of volatile emission and biological impact of volatile compounds on Arabidopsis thaliana. Appl. Microbiol. Biotechnol. 88, 965-976. doi: 10.1007/s00253-010-2810-1

Kai, M., Effmert, U., Berg, G., and Piechulla, B. (2007). Volatiles of bacterial antagonists inhibit mycelial growth of the plant pathogen Rhizoctonia solani. Arch. Microbiol. 187, 351-360. doi: 10.1007/s00203-00 6-0199-0

Kai, M., Haustein, M., Molina, F., Petri, A., Scholz, B., and Piechulla, B. (2009). Bacterial volatiles and their action potential. Appl. Microbiol. Biotechnol. 81, 1001-1012. doi: 10.1007/s00253-008-1760-3

Kai, M., and Piechulla, B. (2009). Plant growth promotion due to rhizobacterial volatiles - an effect of $\mathrm{CO}_{2}$ ? FEBS Lett. 583, 3473-3477. doi: 10.1016/j.febslet.2009.09.053

Kai, M., and Piechulla, B. (2010). Impact of volatiles of the rhizobacteria Serratia odorifera on the moss Physcomitrella patens. Plant Signal. Behav. 5, 444-446. doi: $10.4161 / p s b .5 .4 .11340$

Kai, M., Vespermann, A., and Piechulla, B. (2008). The growth of fungi and Arabidopsis thaliana is influenced by bacterial volatiles. Plant Signal. Behav. 3, 482-484. doi: $10.4161 / \mathrm{psb}$.3.7.5681

Kesarwani, M., Hazan, R., He, J., Que, Y., Apidianakis, Y., Lesic, B., et al. (2011). A quorum sensing regulated small volatile molecule reduces acute virulence and promotes chronic infection phenotypes. PLoS Pathog. 7:e1002192. doi: 10.1371/journal.ppat.1002192

Knollhoff, L. M., and Heckel, D. G. (2014). Behavioral assays for studies of host plant choice and adaptation in herbivorous insects. Annu. Rev. Entomol. 59, 263-278. doi: 10.1146/annurev-ento-011613-161945

Lenc, L., Kwasna, H., and Sadowski, C. (2011). Dynamics of the root/soil pathogens and antagonists in organic and integrated production of potato. Eur. J. Plant Pathol. 131, 603-620. doi: 10.1007/s10658-011-9834-y

Leven, L., Eriksson, A. R. B., and Schnürer, A. (2007). Effect of process temperature on bacterial and archaeal communities in two methanogenic bioreactors treating organic household waste. FEMS Microbiol. Ecol. 59, 683-693. doi: 10.1111/j.1574-6941.2006.00263.x 
Lowery, C. A., Dickerson, T. J., and Janda, K. D. (2008). Interspecies and interkingdom communication mediated by bacterial quorum sensing. Chem. Soc. Rev. 37, 1337-1346. doi: 10.1039/b702781h

Lynch, J. M., and Whipps, J. M. (1991). "Substrate flow in the rhizosphere," in The Rhizosphere and Plant Growth, eds D. L. Keister and B. Cregan (Dordrecht: Kluwer Academic Publishers), 15-24. doi: 10.1007/978-94-011-3336-4_2

Marschner, H. (1995). Mineral Nutrition of Higher Plants, 2nd Edn. London: Academic.

Matz, C., and Kjelleberg, S. (2005). Off the hook - how bacteria survive protozoan grazing. Trends Microbiol. 13, 302-307. doi: 10.1016/j.tim.2005.05.009

Mithöfer, A., and Boland, W. (2012). Plant defense against herbivores: chemical aspects. Annu. Rev. Plant Biol. 63, 431-450. doi: 10.1146/annurev-arplant042110-103854

Moore, B. D., Andrew, R. L., Kühlheim, C., and Foley, W. J. (2014). Explaining intraspecific diversity in plant secondary metabolites in an ecological context. New Phytol. 201, 733-750. doi: 10.1111/nph.12526

Nannipieri, P., Ascher, J., Ceccherini, M. T., Landi, L., Pietramellara, G., Renella, G., et al. (2007). Microbial diversity and microbial activity in the rhizosphere. Ciencia del Suelo (Argentina) 25, 89-97.

O'Sullivan, D. J., and O'Gara, F. (1992). Traits of fluorescent Pseudomonas spp. involved in suppression of plant root pathogens. Microbiol. Rev. 56, 662-676.

Orozco-Mosqueda, M. C., Velázquez-Becerra, C., Macías-Rodríguez, L. I., Santoyo, G., Flores-Cortez, I., Alfaro-Cuevas, R., et al. (2013). Arthrobacter agilis UMCV2 induces iron acquisition in Medicago truncatula (strategy I plant) in vitro via dimethylhexadecylamine emission. Plant Soil 362, 51-66. doi: 10.1007/s11104-012-1263-y

Park, Y. S., Dutta, S., Ann, M., Raaijmakers, J. M., and Park, K. (2015). Promotion of plant growth by Pseudomonas fluorescens strain SS101 via novel volatile organic compounds. Biochem. Biophys. Res. Commun. 461, 361-365. doi: 10.1016/j.bbrc.2015.04.039

Perry, L. G., Alford, E. R., Horiuchi, J., Paschke, M. W., and Vivanco, J. M. (2007). "Chemical signals in the rhizosphere: root-root and root-microbe communication," in The Rhizosphere. Biochemistry and Organic Substances at the Soil-Plant Interface, 2nd Edn., eds R. Pinton, Z. Varanini, and P. Nannipieri (Boca Raton, FL: CRC Press; Taylor and Francis Group), 297-330.

Pliego, C., De Weert, S., Lamers, G., De Vicente, A., Bloemberg, G., Cazorla, F. M., et al. (2008). Two similar enhanced root-colonizing Pseudomonas strains differ largely in their colonization strategies of avocado roots and Rosellinia neatrix hyphae. Environ. Microbiol. 10, 3295-3304. doi: 10.1111/j.14622920.2008.01721.x

Rasmann, S., Kollner, T. G., Degenhardt, J., Hiltpold, I., Toepfer, S., Kuhlmann, U., et al. (2005). Recruitment of entomopathogenic nematodes by insect-damaged maize roots. Nature 434, 732-737. doi: 10.1038/nature03451

Reinhold-Hurek, B., Bünger, W., Burbano, C. S., Sabale, M., and Hurek, T. (2015). Roots shaping their microbiome: global hotspots for microbial activity. Annu. Rev. Phytopathol. 53, 403-424. doi: 10.1146/annurev-phyto-082712-102342

Ronn, R., Vestergard, M., and Ekelund, F. (2012). Interactions between bacteria, protozoa and nematodes in soil. Acta Protozool. 51, 223-235. doi: 10.4467/16890027AP.12.018.0764

Rudrappa, T., Biedrzycki, M. L., Kunjeti, S. G., Donofrio, N. M., Czymmek, K. J., Paré, P. W., et al. (2010). The rhizobacterial elicitor acetoin induces systemic resistance in Arabidopsis thaliana. Commun. Integr. Biol. 3, 130-138. doi: 10.4161/cib.3.2.10584

Rudrappa, T., Czymmek, K. J., Pare, P. W., and Bais, H. P. (2008). Root-secreted malic acid recruits beneficial soil bacteria. Plant Physiol. 148, 1547-1556. doi: 10.1104/pp.108.127613

Ryu, C. M., Farag, M. A., Hu, C. H., Reddy, M. S., Kloepper, J. W., and Paré, P. W. (2004). Bacterial volatiles induce systemic resistance in Arabidopsis. Plant Physiol. 134, 1017-1026. doi: 10.1104/pp.103.026583

Ryu, C. M., Farag, M. A., Hu, C. H., Reddy, M. S., Wei, H. X., Paré, P. W., et al. (2003). Bacterial volatiles promote growth in Arabidopsis. Proc. Natl. Acad. Sci. U.S.A. 100, 4927-4932. doi: 10.1073/pnas.0730845100

Ryan, R. P., and Dow, J. M. (2008). Diffusible signals and interspecies communication in bacteria. Microbiology 154, 1845-1858. doi: 10.1099/mic.0.2008/017871-0

Schmidt, R., Cordovez, V., de Boer, W., Raaikmakers, J., and Garbeva, P. (2015a). Volatile affairs in microbial interactions. ISME J. 9, 2329-2335. doi: 10.1038/ismej.2015.42
Schmidt, R., Etalo, D. W., de Jager, V., Gerards, S., Zweers, H., De Boer, W., et al. (2015b). Microbial small talk: volatiles in fungal-bacterial interactions. Front. Microbiol. 6:1495. doi: 10.3389/fmicb.2015.01495

Schulz-Bohm, K., Zweers, H., de Boer, W., and Garbeva, P. (2015). A fragrant neighborhood: volatile mediated bacterial interactions in soil. Front. Microbiol. 6:1212. doi: 10.3389/fmicb.2015.01212

Sexstone, A. J., Revsbech, N. P., Parkin, T. B., and Tiedje, J. M. (1985). Direct measurement of oxygen profiles and denitrification rates in soil aggregates. Soil Sci. Soc. Am. J. 49, 645-651.

Shank, E. A., and Kolter, R. (2009). New developments in microbial interspecies signaling. Curr. Opin. Microbiol. 12, 205-214. doi: 10.1016/j.mib.2009.01.003

Spaink, H. P., Kondorosi, A., and Hooykaas, P. J. J. (1998). The Rhizobiaeceae. Dordrecht: Kluwer Acad.

Splivallo, R., Deveau, A., Valdez, N., Kirchhoff, N., Frey-Klett, P., and Karlovsky, P. (2015). Bacteria associated with truffle-fruiting bodies contribute to truffle aroma. Environ Microbiol. 17, 2647-2660. doi: 10.1111/1462-2920.12521

Stepniewski, W., and Stepniewska, Z. (2009). Selected oxygen-dependent process-response to soil management and tillage. Soil Till. Res. 102, 193-200. doi: 10.1016/j.still.2008.07.006

Strzelczyk, E., and Pokojska-Burdziej, A. (1984). Production of auxins and gibberellin-like substances by mycorrhizal fungi, bacteria and actinomycetes isolates from soil and the myorrhizosphere of pine (Pinus silvestris L.). Plant Soil 81, 185-194. doi: 10.1007/BF02197150

Tholl, D., and Röse, U. S. R. (2006). "Detection and identification of floral scent compounds," in Biology of Floral Scent, eds N. Dudarevea and E. Pichersky (Boca Raton, FL: CRC Press; Taylor and Francis Group), 3-25. doi: 10.1201/9781420004007.sec1

Thomashow, L. S., Weller, D. M., Bonsall, R. F., and Pierson, L. S. P. III. (1990). Production of the antibiotic phenazine-1-carboxylic acid by fluorescent Pseudomonas species in the rhizosphere of wheat. Appl. Environ. Microbiol. 56, 908-912.

Tyk, O., van den Berg, M., Gerards, S., van Veen, J. A., Raaijmakers, J. M., de Boer, W., et al. (2014). Impact of interspecific interactions on antimicrobial activity among soil bacteria. Front. Microbiol. 5:567. doi: 10.3389/fmicb.2014.00567

Uren, N. C. (2007). "Types, amounts, and possible functions of compounds released into the rhizosphere by soil-grown plants," in The Rhizosphere. Biochemistry and Organic Substances at the Soil-Plant Interface, 2nd Edn.,eds R. Pinton, Z. Varanini, and P. Nannipieri (Boca Raton, FL: CRC Press; Taylor and Francis Group), 1-21. doi: 10.1201/9781420005585.ch1

Uteau, D., Hafner, S., Kouso Papenkemper, S., Peth, S., Wiesenberg, G. L. B., Kuzyakov, Y., et al. (2015). Oxygen and redox potential gradients in the rhizosphere of alfalfa grown on a loamy soil. J. Plant Nutr. Soil Sci. 178, 278-287. doi: 10.1002/jpln.201300624

Van Dam, N. M., Tygat, T. O. G., and Kirkegaard, J. A. (2009). Root and shoot glucosinolates: a comparison of their diversity, function and interactions in natural and managed ecosystems. Phytochem. Rev. 8, 171-186. doi: 10.1007/s11101-008-9101-9

van Rhijn, P., and Vanderleyden, J. (1995). The Rhizobium-plant symbiosis. Microbiol. Rev. 59, 124-142.

Velázquez-Becerra, C., Macías-Rodríguez, L. I., López-Bucio, J., AltamiranoHernández, J., Flores-Cortez, I., and Valencia-Cantero, E. (2011). A volatile organic compound analysis from Arthrobacter agilis identifies dimethylhexadecylamine, an amino-containing lipid modulating bacterial growth and Medicago sativa morphogenesis in vitro. Plant Soil 339, 329-340. doi: $10.1007 / \mathrm{s} 11104-010-0583-\mathrm{z}$

Vespermann, A., Kai, M., and Piechulla, B. (2007). Rhizobacterial volatiles affect the growth of fungi and Arabidopsis thaliana. Appl. Environ. Microbiol. 73, 5639-5641. doi: 10.1128/AEM.01078-07

von Reuss, S, H., Kai, M., Piechulla, B., and Francke, W. (2010). Octamethylbicyclo(3.2.1)octadienes from Serratia odorifera. Angew. Chem. Int. Ed. 49, 2009-2010. doi: 10.1002/anie.200905680

Voroney, R. P., and Heck, R. J. (2015). “The soil habitat," in Soil Microbiology, Ecology, and Biochemistry, 4th Edn., ed E. A. Paul (Amsterdam: Elsevier Academic Press), 15-39. doi: 10.1016/b978-0-12-415955-6.00002-5

Watrous, J., Roach, P., Alexandrov, T., Heath, B. S., Yang, J. Y., Kersten, R. D., et al. (2012). Mass spectral molecular networking of living microbial colonies. Proc. Natl. Acad. Sci. U.S.A. 109, E1743-E1752. doi: 10.1073/pnas.12036 89109 
Weise, T., Kai, M., and Piechulla, B. (2013). Bacterial ammonia causes significant plant growth inhibition. PLOS ONE 8:e63538. doi: 10.1371/journal.pone.0063538

Wenke, K., Kai, M., and Piechulla, B. (2010). Belowground volatiles facilitate interactions between plant roots and soil organisms. Planta 231, 499-506. doi: 10.1007/s00425-009-1076-2

Wenke, K., Wanke, D., Kilian, J., Berendzen, K., Harter, K., and Piechulla, B. (2012). Volatiles of two growth-inhibiting rhizobacteria commonly engage AtWRKY18 function. Plant J. 70, 445-459. doi: 10.1111/j.1365313X.2011.04891.x

Xie, X., Zhang, H., and Paré, P. W. (2009). Sustained growth promotion in Arabidopsis with long-term exposure to the beneficial soil bacterium Bacillus subtilis (GB03). Plant Signal. Behav. 4, 948-953. doi: 10.4161/psb.4. 10.9709

Zamioudis, C., Korteland, J., Van Pelt, J. A., van Hamersveld, M., Dombrowski, N., Bai, L., et al. (2015). Rhizobacterial volatiles and photosynthesis-related signals coordinate MYB72 in Arabidopsis roots during onset of induced systemic resistance and iron deficiency responses. Plant J. 84, 309-322. doi: 10.1111/tpj. 12995

Zausig, J., Stepniewski, W., and Horn, R. (1993). Oxygen concentration and redox potential gradients in unsaturated model soil aggregates. Soil Sci. Soc. Am. J. 57, 908-916.
Zhang, H., Kim, M. S., Krishnamachari, V., Payton, P., Sun, Y., Grimson, M., et al. (2007). Rhizobacterial volatile emissions regulate auxin homeostasis and cell expansion in Arabidopsis. Planta 226, 839-851. doi: 10.1007/s00425-00 7-0530-2

Zhou, J., Ma, Q., Yi, H., Wang, L., Song, H., and Yuan, Y-J. (2011). Metabolome profiling reveals metabolic cooperation between Bacillus megaterium and Ketogulonicigenium vulgare during induced swarm motility. Appl. Environ. Microbiol. 77, 7023-7030. doi: 10.1128/AEM.05123-11

Zou, C., Li, Z., and Yu, D. (2010). Bacillus megaterium strain XTBG34 promotes plant growth by producing 2-pentylfuran. J. Microbiol. 48, 460-466. doi: 10.1007/s12275-010-0068-z

Conflict of Interest Statement: The authors declare that the research was conducted in the absence of any commercial or financial relationships that could be construed as a potential conflict of interest.

Copyright (c) $2016 \mathrm{Kai}$, Effmert and Piechulla. This is an open-access article distributed under the terms of the Creative Commons Attribution License (CC BY). The use, distribution or reproduction in other forums is permitted, provided the original author(s) or licensor are credited and that the original publication in this journal is cited, in accordance with accepted academic practice. No use, distribution or reproduction is permitted which does not comply with these terms. 